Gazi Mühendislik Bilimleri Dergisi

2020, 6(3): 217-229

Araştırma Makalesi/Research Article

https://dergipark.org.tr/gmbd

\title{
Tanıtım Festivalinde Personel Çizelgeleme Problemi: Bir Uygulama
}

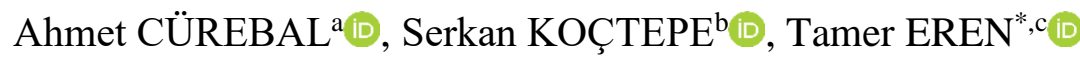

a Kırıkkale Üniversitesi Endüstri Mühendisliği Bölümü, 71450, KIRIKKALE, TÜRKIYYE

${ }^{b}$ Kırlkkale Üniversitesi Elektrik Elektronik Mühendisliği Bölümü, 71450, KIRIKKALE, TÜRKİYE

${ }^{c,}{ }^{*}$ Kirlkkale Üniversitesi Elektrik Elektronik Mühendisliği Bölümü, 71450, KIRIKKALE, TÜRKIYE

\begin{tabular}{l} 
MAKALE \\
BILGÍSI \\
\hline Alınma: 07.10.2020 \\
Kabul: 13.12.2020 \\
\hline \\
Anahtar Kelimeler: \\
Personel Çizelgeleme, \\
Hedef Programlama, \\
Analitik Hiyerarşi \\
Süreci (AHP) \\
"Sorumlu Yazar: \\
e-posta: \\
tamereren@ gmail.com
\end{tabular}

ÖZ

Tanıtım organizasyonları, kuruluşların, günden güne artan rekabet ortamında ellerinde bulunan en büyük kozlardan birisidir. Özellikle müşterilerinin sınırsız alternatife sahip olduğu, turizm sektörü için bu tarz etkinlikler oldukça önemlidir. Artan hizmet beklentisi ve geri dönüşlerin hızlı bir şekilde alınması bu etkinlikleri daha da önemli kılmaktadır. Bu etkinliklerin önemi ve hassaslığından dolayı etkinlik sahipleri bu süreci yöneten profesyonel firmalardan hizmet almaktadır. Organizasyonlar hem hizmeti alan ve hem de sağlayan kuruluşlar için oldukça önemlidir ve titizlikle planlanması gerekmektedir. Süreç boyunca herhangi olumsuz bir durumun yaşanmaması oldukça önemlidir. Bu gibi olası durumların, personellerin yetkin oldukları işlere atanması ile, mümkün olduğunca önüne geçilmesi gerekmektedir. Personellerin yetkin oldukları işlere atanması hem personel memnuniyetine hem de hizmet kalitesine katkı sağlayacaktır. Dolayısıyla bu tarz etkinliklerde bilimsel yöntemlerin kullanıldığı bir çalışma planı yürütmek gerekmektedir. Bu çalışmada, önemli bir turistik bölge olan Kapadokya'da tanıtım amaçlı yürütülen, özellikle de yabancı turistlere hitap eden bir etkinliğin personel çizelgeleme çalışması yürütülmüştür. 15 gün sürecek etkinlikte 84 adet personel 6 görev altında hizmet verecektir. Çalışma kapsamında organizasyonda yürütülecek görevler AHP yöntemi ile önceliklendirilmiş, ardından personellerin yetkinliklerini ve görevlerin önem derecelerini dikkate alan bir hedef programlama modeli kurulmuştur.

\section{The Staff Scheduling Problem at The Promotion Festival: An Application}

\section{ARTICLE \\ INFO \\ Received: 07.10.2020 \\ Accepted: 13.12.2020 \\ Keywords: \\ Staff Scheduling, Goal \\ Programming, \\ Analytic Hierarchy \\ Process (AHP) \\ "Corresponding \\ Authors \\ e-mail: \\ tamereren@gmail.com}

\begin{abstract}
Promotion organizations are one of the biggest trump cards of organizations in the increasingly competitive environment. Such events are very important, especially for the tourism sector where customers have unlimited alternatives. Increasing service expectation and rapid feedback make these activities even more important. Due to the importance and sensitivity of these events, event owners receive service from professional companies that manage this process. Organizations are very important for both service providers and organizations and must be carefully planned. It is very important not to experience any negative situations during the process. Such possible situations should be avoided as much as possible by assigning the personnel to jobs in which they are competent. Appointment of personnel to jobs in which they are competent will contribute to both personnel satisfaction and service quality. Therefore, it is necessary to carry out a work plan in which scientific methods are used in such activities. In this study, a staff scheduling study was carried out for a promotional event in Cappadocia, which is an important touristic region, especially for foreign tourists. 84 personnel will serve under 6 tasks in the 15-day event. Within the scope of the study, the tasks to be carried out in the organization were prioritized with the AHP method, and then a goal programming model was established that takes into account the competencies of the personnel and the importance of the tasks.
\end{abstract}

https://dx.doi.org/10.30855/gmbd.2020.03.05

Bu makaleye atıf yapmak için: A. Cürebal, S. Koçtepe ve T. Eren, "Tanıtım Festivalinde Personel Çizelgeleme Problemi: Bir Uygulama," Gazi Mühendislik Bilimleri Dergisi, cilt 6, sayı 3, s. 217-229, Aralık, 2020, doi: https://dx.doi.org/10.30855/gmbd.2020.03.05. 


\section{GIRISS (INTRODUCTION)}

Günümüzde hizmet ağı gelişimi ile firmalar, müşteri kazanmalarının yanında rekabet ettikleri firma sayısında da bir artışla karşılaşmaktadırlar. Özellikle yerel firmalar dünya çapında hizmet veren kuruluşlarla rekabet etmek durumunda kalmaktadır. Artan rekabet ortamı müşteri beklentisini de artırmaktadır ve bu durum bütün sektörler için geçerlidir. Özellikle turizm sektörü düşünüldüğü zaman müşterilerin alternatifleri dünya ile sınırlıdır. $\mathrm{Bu}$ ortamda, hizmet sağlayıcıları hizmet kalitelerini artırmanın yanında kendilerini tanıtma mecburiyeti de hissetmektedir. Tanıtım organizasyonları firmalar için ilk izlenim niteliğindedir, bu nedenle firmalar bu konuda profesyonel kuruluşlardan hizmet alarak sürecin etkin bir şekilde işlemesini istemektedir. Bu organizasyonlar hem hizmeti alan hem de sunan firma için bir prestij göstergesidir ve oldukça hassas bir şekilde yürütülmelidir. Dolayısıyla planlama aşamasında bilimsel yöntemler kullanılması oldukça önemlidir.

Türkiye Seyahat Acentaları Birliği (TURSAB) verilerine göre 2018 yllında Türkiye'de, turizm gelirleri toplam gelirlerinin \%3,8'ini oluşturmaktadır [1]. Dünya çapında turistik gezilere olan ilginin arttığ düşünüldüğünde bu değerin de her yıl artması beklenmektedir. Turizm sektörünün her geçen gün daha global hale gelmesi ile hemen hemen tüm ülkeler bu sektör için rekabet halindedir. Dolayısıyla ülkeler kendi tanıtımlarına ve gelen turistlerin organizasyonlarına oldukça önem göstermek durumundadır. Turistik tanıtım organizasyonları hem ülke tanıtımı hem de gelmiş olan turistlerin beklentilerini karşılamak açısından oldukça önemlidir. Bu organizasyonlarda olabilecek herhangi bir aksama prestij açısından diğer sektörlere nazaran daha büyük bir kayıp oluşturacaktır. Bu olumsuz durumun getireceği maddi kayıp da düşünüldüğü zaman bu tarz organizasyonların, tüm aşamalarının etkili bir şekilde planlanması elzemdir. Organizasyon çalışmalarını sürdüren personelin refah şartlarda çalışması ve yetkinliklerine göre uygun işlere atanması organizasyonun sürdürülebilirliği açısından hayati öneme sahiptir. Geri dönüşü en hızlı sektör olan turizm sektöründeki herhangi bir aksama diğer sektörlere nazaran daha büyük ve geri dönülemez zararlar verecektir.

$\mathrm{Bu}$ çalışmada ele alınan personel çizelgeleme probleminde, görev önceliklerini belirlemek için AHP yöntemi ve görevlerin de önemleri ile orantılı olarak yetkinlik puanlarının ençoklanması amacı ile hedef programlama yöntemi kullanılmıştır. Kapadokya bölgesinde düzenlenen bir festival organizasyonunda müzik, gastronomi, çağdaş sanat ve açık hava sergileri olmak üzere dört etkinlik düzenlenecektir. Düzenlenen etkinliklerin günlere dağılması personel çizelgeleme problemini etkileyen önemli bir noktadır. $\mathrm{Bu}$ çalışmada amaç personel memnuniyetini sağlamak, uygun görevlere, uygun personellerin atanması ile kaliteli bir organizasyon hizmeti sunmak ve herhangi olası bir aksamanın önüne geçmektir.

Çalışma planı şu şekildedir; ikinci bölümünde organizasyon çalışmaları hakkında bilgi verilmiş üçüncü bölümünde ise problem çözümünde ele alınan yöntemlerden bahsedilmiştir. Çalışmanın dördüncü bölümünde konu ile ilişkili literatürde bulunan çalışmalar incelenmiş ve bu çalışmanın literatüre olan katkılarından bahsedilmiştir. Beşinci bölümde çalışma problemi açıklanmış ve çözülmüştür, altıncı bölümde ise çözüm sonuçları değerlendirilmiş ve diğer çalışmalar için öneri ve fikirler tartışılmıştır.

\section{ORGANIZASYON ÇALIŞMALARI (ORGANIZATIONAL WORKS)}

Türkiye' de her yıl çeşitli sektörler adına düzenlenen ve organizasyon olarak nitelendirilebilecek büyük çapta birçok proje gerçekleşmektedir. Bu tip projeler her geçen gün niteliklerini artırmakta ve daha fazla talep görmektedir. $\mathrm{Bu}$ değişim ile birlikte organizasyon düzenleme işi bir sektör haline gelmiş ve bu işe odaklanarak profesyonel hizmet sunan firmalar ortaya çıkmıştır. Özel bir araştırma şirketinden alınan verilere göre; Türkiye'de sadece eğlence sektöründe yapılan organizasyon sayısı 40.000 civarındadır ve bu organizasyonlara ayrılan bütçe yaklaşık 4 milyar dolardir [2].

Organizasyon çalışmaları, günümüzde birçok sektörün etkinlik ve benzeri ihtiyaçlarını karşılamaktadır. Firmalar, iş toplantıları, kongreleri, fuarları ve genel şirket içi toplantıları başlıca olmak üzere birçok etkinliklerini profesyonel organizasyon şirketlerinden hizmet alarak gerçekleştirmektedirler. Artan talep ile beraber organizasyon kuruluşları da yoğun bir rekabet içerisindedir. Bu rekabette fark yaratabilmek için teknik ekipmanlar, personeller ve hizmet alınan tedarikçilerden maksimum verimi almaya çalışmaktadırlar. Organizasyonların 
kapasitesine göre tedarikçi firmalardan personel hizmeti alınabilmektedir. $\mathrm{Bu}$ ekipler belirlenen görevlere atanmak üzere görevlendirilir. $\mathrm{Bu}$ yarı zamanlı olarak temin edilen personellere mice ekibi denmektedir. Organizasyon şirketlerinin ana bileşenleri arasında bulunan bu üç yapı (personel, teknik ekipman ve mice ekipleri) organizasyonun hem kalitesi hem de müşteri memnuniyeti açısından en önemli faktörler olarak düşünülmektedir. Planlanan organizasyonun istenilen seviyede olabilmesi; organizasyonda görev alan personellerin yetkinlikleri, teknik ekipmanın yeterliliği ve süreci yöneten birimlerin entegre olarak çalışmasına bağlıdır. Personellerin verilen görevin niteliklerine uygun olmas1, personel memnuniyeti ve organizasyon kalitesi bakımından son derece önemlidir. Organizasyon planlaması yapılırken en önemli hususlardan bir tanesi, personellerin hangi görevlerde ve süreçlerde değerlendirilebileceğidir. Organizasyonun amaçlarının yerine getirilebilmesi açısından personellerin görev dağılımı çalışması oldukça önemli bir süreçtir.

Organizasyonlar genel olarak açık alan organizasyonları ve kapalı alan organizasyonları olmak üzere ikiye ayrılır. Organizasyonlar, aranılan personel tipleri ve özellikleri Tablo 1'de gösterilmiştir.

Tablo 1. Organizasyon ve Personel Çeşitleri (Organizations and Staff Types)

\begin{tabular}{|l|l|}
\hline Organizasyon & Personel Tipleri \\
\hline Fuar & $\begin{array}{l}\text { Sahne teknik ekibi, Stant teknik ekibi, } \\
\text { Salon içi görevli ekibi, Stant görevlisi } \\
\text { ekip, Birimlerin sorumluları, Genel ekip } \\
\text { sorumlusu }\end{array}$ \\
\hline Seminer & $\begin{array}{l}\text { Sahne teknik ekibi, Salonlarda görevli } \\
\text { ekip, Salon genel sorumlusu }\end{array}$ \\
\hline Kongre & $\begin{array}{l}\text { Sahne teknik ekibi, karşılama ekibi, } \\
\text { transfer ekibi, salon ekipleri, Ekip } \\
\text { sorumluları, Kayıt ekibi, Gerekli kontak ve } \\
\text { akış kontrolü ile ilgili organizasyon } \\
\text { yetkilisi ve Genel ekip sorumlusu }\end{array}$ \\
\hline $\begin{array}{l}\text { Lansman kurulum ekibi, Merchandiser (Satış } \\
\text { Oestek elemanı), Stant ekibi, Stant } \\
\text { Sorumlusu }\end{array}$ \\
\hline Festival, Konser & $\begin{array}{l}\text { Teknik kurulum ekibi, Bilet satı̧̧ ekibi, } \\
\text { Bilet kontrol ekibi, Yönlendirme ekibi, } \\
\text { Ekip sorumluları, Genel ekip sorumlusu }\end{array}$ \\
\hline Eğlence, Parti & $\begin{array}{l}\text { Kostümlü veya serbest giyimli eğlence } \\
\text { ekibi, eğlence ve müzik için dj, Animatör, } \\
\text { Palyaço ekibi, Yönlendirme ekibi, Genel } \\
\text { ekip sorumlusu }\end{array}$ \\
\hline Sergi & $\begin{array}{l}\text { Teknik kurulum ekibi, Stant ekibi, Stant } \\
\text { sorumlusu }\end{array}$ \\
\hline
\end{tabular}

Organizasyon çalışmaları; anlık olarak geri dönüşlerin alınması ve prestij göstergesi olarak görülmesi açısından oldukça hassas yürütülmesi gereken çalışmalardır. Geri dönüşün hızlı bir şekilde alınması ve herhangi bir aksamanın geri dönülemez oluşundan dolayı görevli personelin yönlendirilmesi birçok sektörden daha önemlidir. Organizasyonlar için personel belirleme süreci en genel hali ile birlikte Şekil 1'de gösterilmiştir.

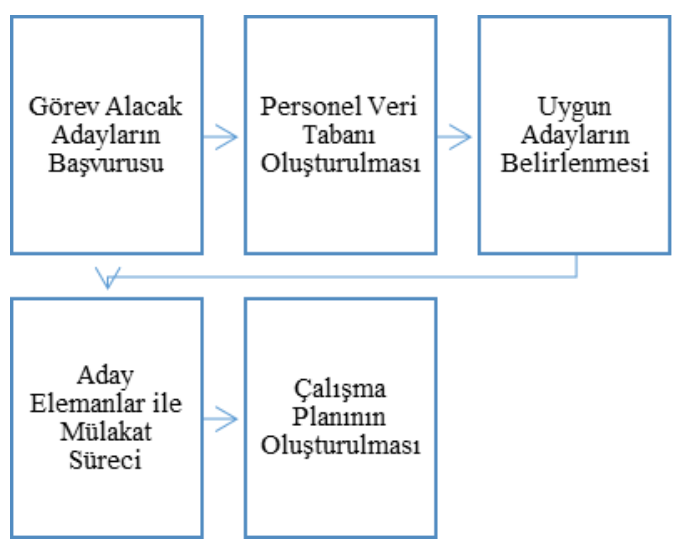

Şekil 1. Organizasyonlar için Genel Personel Belirleme Süreci (General Personnel Selection Process in Organizations)

\section{YÖNTEMLER (METHODS)}

$\mathrm{Bu}$ bölümde problem çözümünde kullanılan yöntemler anlatılmıştır. Personellerin atanacakları görevler belirlenirken hedef programlama yöntemi kullanılmıştır. Her personelin en uygun olduğu işe atanması amaçlanmıştır. Böylece hizmet kalitesi ençoklanacaktır. Ayrıca çalışma boyunca ihtiyaç duyulan görevler önem derecelerine göre sıralanmıştır. Bu sıralama ise AHP yöntemi ile belirlenmiştir. Görevler önem ağırlıklarına göre sıralanmış ve bu sıralama hedef programlama modelindeki hedeflere yansıtılmıştır. Çalışmada hedef programlama ve AHP yöntemi kullanılmıştır.

\subsection{Hedef Programlama Yöntemi (Goal Programming)}

Hedef programlama, matematiksel programlama metotlarından en çok kullanılan yöntemlerinden bir tanesidir. Diğer matematiksel yöntemlerden en büyük fark1, karar vericiye alternatif sonuçlar da sunabilmesidir. Karar verici herhangi bir kısıtından herhangi bir oranda sapabildiği taktirde amaç fonksiyonuna ne kadar katkısı olacağını yöntem sayesinde gözlemleyebilmektedir. Hedef programlama yönteminin amacı genel olarak; ulaşılmak istenen hedefler arasındaki sapmaları enküçüklemektir. Hedef programlama yönteminin amaç fonksiyonu sadece sapmalardan oluşmaktadır [3]. Yöntemin genel formülasyonu eşitlik 1-3'te gösterilmektedir.

$x_{j}:$ j. karar değişkeni

$a$ : karar değişkeni katsayı parametresi 
$\mathrm{r} \quad$ : hedef kısıtı sağ taraf değer parametresi

$d_{i}^{+}:$i. hedefin pozitif sapma değişkeni

$d_{i}^{-}:$i. hedefin negatif sapma değişkeni

$\mathrm{P}$ : hedef önem derecesi

Olmak üzere:

Min. $\mathrm{Z}=\sum_{i=1}^{n} P *\left(d_{i}{ }^{+}, d_{i}{ }^{-}\right)$

$\sum_{j=1}^{n} a * x_{j}+d_{i}^{+}+d_{i}^{-}=\mathrm{r}$

$x_{j}, d_{i}^{+}, d_{i}^{-} \geq 0$

$\mathrm{i}=1 \ldots \mathrm{m}, \mathrm{j}=1 \ldots \mathrm{n}$

\section{LITERATÜR TARAMASI (LITERATURE REVIEW)}

Personel çizelgeleme problemi oldukça fazla çalışılmış ve üzerinde çeşitli yöntemler kullanılmış geniş bir problemdir. Bu bölümde literatürde bulunan benzer çalışmalar özetlenmiştir.

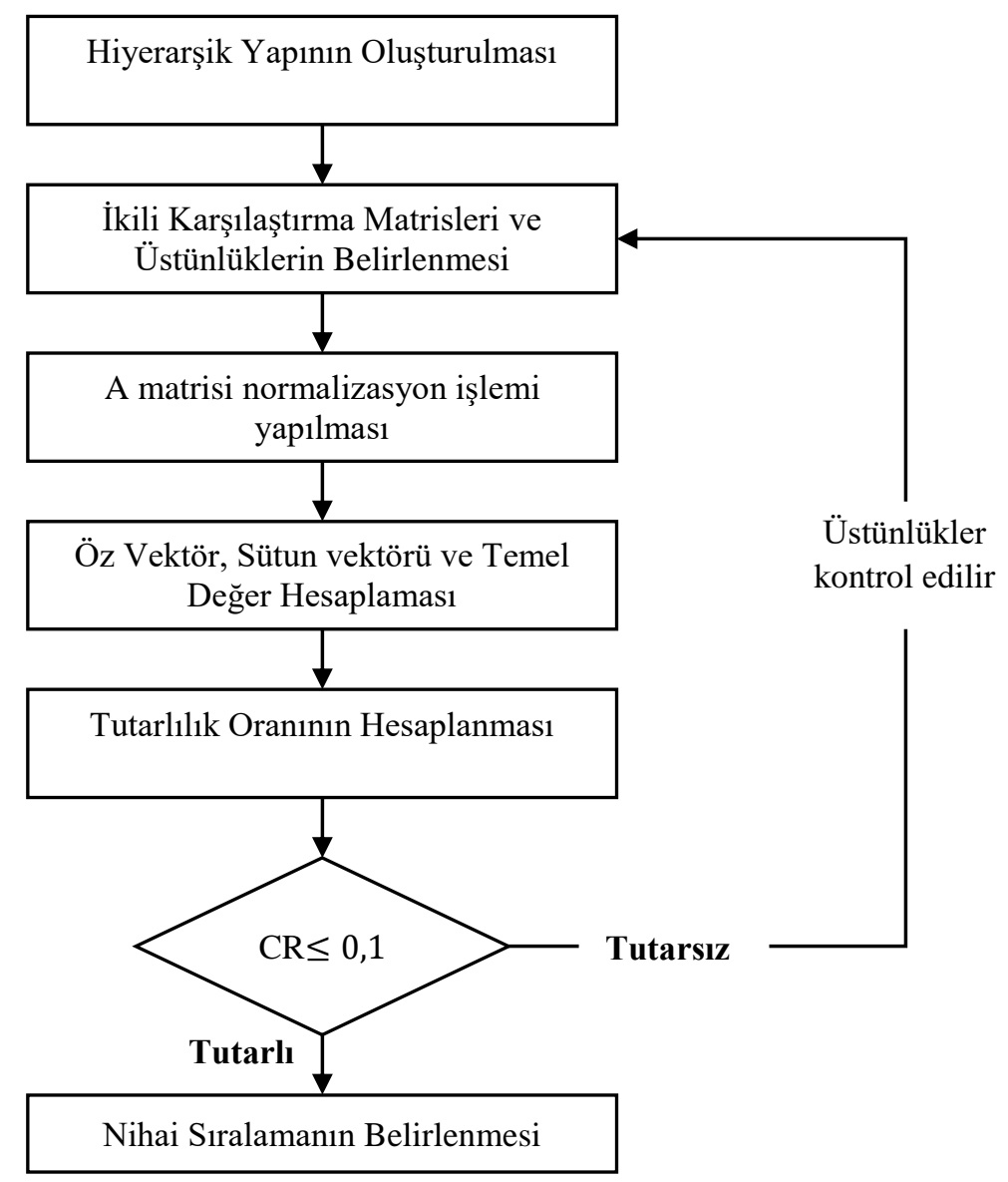

Şekil 2. AHP Yöntemi Akış Şeması (AHP method flow chart)

\subsection{AHP Yöntemi (Analytic Hierarchy Process)}

AHP, 1970'li yıllarda Thomas Saaty (1977) tarafindan geliştirilmiş çok kriterli karar verme yöntemidir. Metot, belirlilik veya belirsizlik altında çok sayıda alternatif arasından seçim yaparken, çok sayıda karar vericinin bulunduğu, çok kriterli karar verme durumunda kullanılır. Bu yöntem bir karar verme durumunda, veriler kadar değerli olan bilgi ve deneyimlerin de dikkate alınması ilkesine dayanır [4]. AHP yönteminin akış şeması Şekil 2'de gösterilmiştir.
Tsai ve Li [5] çalışmalarında hemşire çizelgeleme problemini ele almışlardır. Çalışmalarında hemşire taleplerine de duyarlı bir model oluşturmuşlardır ve çözüm yöntemi olarak Genetik algoritma ve Tamsayılı programa kullanmışlardır. Girginer ve Kaygısız [6] çalışmalarında AHP ve 0-1 hedef programlama yöntemlerini kullanarak, en uygun istatiksel yazılımı belirlemişlerdir. Lezaun vd. [7] 
demiryolu çalışanları için bir vardiya çizelgeleme problemini ele almışlardır ve personel taleplerini de göz önünde bulunduran bir model oluşturmuşlardır.

Çözüm yöntemi olarak Karma tamsayılı programlama kullanmışlardır. Hung-Tso vd. [8] personel çizelgeleme problemini ele almışlardır ve kısıtları dikkate alan matematiksel bir model ile çözüm önerisinde bulunmuşlardır. Bektur ve Hasgül [9] çalışmalarında, çizelgeleme oluşturulması sırasında çalışanların yetkinlikleri, kıdem seviyeleri ve sistemin istekleri göz önünde bulundurularak işgücünün görevlere, vardiyalara ve izin günlerine atanmasını amaçlamışlardır. Kassa vd. [10] otel personelinin eşit sayıda vardiyalara atanmasını sağlayacak bir matematiksel model kurmuşlardır ve özel istek kısıtlarını da modele yansıtmışlardır. Çözüm yöntemi olarak yöneylem araştırması konularından tamsayılı programlama yöntemini kullanmışlardır. Louly vd. [11] bir Telekomünikasyon şirketinde personellerin çizelgelenmesi problemini ele almışlardır ve bir çözüm önerisinde bulunmuşlardır. Çözüm yöntemi olarak hedef programlama yaklaşımını kullanmışlardır. Labidi vd. [12] banka personellerinin çizelgelenmesi problemini ele almışlardır ve bir çözüm önerisinde bulunmuşlardır. Çözüm yöntemi olarak yöneylem araştırması konularından hedef programlama yöntemini kullanmışlardır. Öztürkoğlu ve Çalışkan [13] çalışmalarında, hastanede görevli hemşirelerin çizelgeleme problemi için tam sayılı matematiksel model oluşturulmaktadır. Klasik modellerin aksine oluşturulan çizelgelemede hemşirelerin işe başlama saatlerine esneklik getirilmiştir. Bu modelin başlıca amacı, hemşirelerin yaptıkları işle kendi içinde bulundukları şartları kısa sürede uyumlu hale getirmek için haftalık çizelgelerini kendilerinin hazırlamalarını sağlamaktır. Gerçek veriler kullanılarak oluşturulan bu model bir hastanenin genel cerrahi bölümünde denenmiş ve modelin, hemşirelerin tercihlerini \%99,6 oranında yerine getirdiği görülmüştür. Todorovic vd. [14] polis memurlarının çizelgelenmesi problemini ele almışlardır. Özel durum kısıtlarını da model içerisinde değerlendirmişlerdir. Ünal ve Eren [15] çalışmalarında bir devlet kurumundaki nöbet çizelgeleme problemini, ağırlıklandırılmış hedef programlama yaklaşımı ile ele almışlardır. Problemin çözümü GAMS 22.5 paket programı ile sağlanmıştır. Ciritoğlu vd. [16] güvenlik görevlilerinin vardiyalı çalışma problemi üzerine çalışmalarını yürütmüşlerdir. Çalışmalarında güvenlik görevlilerin günlük atandıkları vardiyaların adil ve dengeli olmasını amaçlamışlardır. Güvenlik görevlilerinin çalışma koşulları farklı açılardan ele alınmış olup, problem çözümünde hedef programlama yönteminden yararlanılmıştır. Bedir vd. [17] Çalışmalarında, ergonomik koşulları da dikkate alan vardiya çizelgeleme çalışmasını ele almışlardır. Problem çözümünde AHP ve hedef programlama yöntemleri kullanılmıştır. Özder vd. [18] çalışmalarında temizlik personeli çizelgeleme problemini ele almışlardır ve personellerin özel kısıtlarını dikkate alarak matematiksel model geliştirmişlerdir. Çözüm yöntemi olarak hedef programlama yaklaşımını kullanmışlardır. Gür vd. [19] çalışmalarında Ankara'da monoray projelerinin seçim problemini ele almışlardır. Belirlenen rotalarda AHP yöntemi kullanılarak kriter önceliklendirmesi yapmışlardır ve bu kriterleri baz alacak şekilde hedefler belirlenmiştir. Birçok duruma göre değişebilen bir çözüm önerisinde bulunmuşlardır. Çözüm yöntemi olarak hedef programlama kullanmışlardır. Varlı vd. [20] bir üniversitede sinav programlama konusunu ele almışlardır. Sınav saatlerinin çakışmama durumu ve öğretim görevlinin uygunluklarını kısıt olarak belirleyecek şekilde matematiksel model kurmuşlardır. Bruecker vd. [21] bakım personellerinin çizelgelenmesi problemini ele almışlardır. Yetkinliklerini kriter olarak alarak yeni bir çizelge önerisinde bulunmuşlardır. Çözüm yöntemi olarak karma tamsayılı programlama kullanmışlardır. Vermuyten vd. [22] sağlık sektöründe görevli personellerin çizelgelenmesi problemini ele almışlardır ve personel taleplerini de dikkate alarak çözüm önerisinde bulunmuşlardır. Koçtepe vd. [23] organizasyon personel çizelgeleme problemini ele almışlardır ve personel yetkinliklerini kriter olarak değerlendirerek, personellerin uygun oldukları görevlere atanması için bir çalışma yapmışlardır. Çizelge oluşturmak için yeni bir çözüm önerisinde bulunmuşlardır. Uslu vd. [24] hemşire çizelgeleme problemini ele almışlardır ve personel taleplerine duyarlı bir çözüm önerisi sunmuşlardır. Özel kısıtlı hemşire taleplerini dikkate alan bir model geliştirmişlerdir. Çözüm yöntemi olarak yöneylem araştırması konularından hedef programlama metodu kullanmışlardır. Yelek vd. [25] Kırıkkale Üniversitesinde kısmi zamanlı çalışan 40 adet öğrencinin bir aylık periyotta çalışma düzeninin belirlenmesi problemini ele almışlardır. Yeni bir çalışma programı önerisinde bulunmuşlardır. Çizelgeyi oluştururken hedef programlama yöntemi ile çözüm bulmuşlardır. Demirel vd. [26] Ankara'da bulunan Ankaray metro hattındaki dört istasyonda çalışan kırk üç personel için personel çizelgeleme problemini ele almışlardır. Çalışma planı çizelgelemesi için yeni bir çözüm önerisinde 
bulunmuşlardır. Çözüm yöntemi olarak yöneylem araştırması konularından hedef programlama kullanmışlardır. Koçtepe vd. [27] çalışmalarında basketbol karşılaşmasında görev alacak personellerin çizelgelenmesi problemini ele almışlardır. Personel yetkinliklerini kriter alarak matematiksel bir model oluşturmuşlardır. 0-1 tamsayılı programlama yöntemi ile bir çözüm önerisinde bulunmuşlardır. Kaçmaz vd. [28] ergonomik personel çizelgeleme problemini ele almışlardır ve personelin çalışma sırasındaki pozisyonları REBA yöntemi ile analiz edilmiştir. Aynı zamanda, hedef programlama kullanılarak bir matematiksel model oluşturulmuştur. Çalışma, personelin ergonomik risk seviyelerini düşürmeyi amaçlamaktadır. Danışan vd. [29] Türkiye'deki büyük ölçekli bir hidroelektrik santralda yer alan 1330 elektriksel ekipman incelenmiş ve santral açısından kritiklik seviyesi belirlenmiştir. AHP, TOPSIS (technique for order preference by similarity to ideal solution) ve tam sayılı programlama yöntemleri kullanılmıştır.

Literatürdeki çalışmalar incelendiğinde görülmektedir ki; personel çizelgeleme problemlerine birçok farklı sektörde birçok farklı yaklaşım sunulmuştur. $\mathrm{Bu}$ çalışmada ele alınan problem bir gerçek hayat problemidir. Söz konusu sektörde bu çalışmalar genel olarak manuel yapılmaktadır. Yapılan çalışma hem hizmeti alan hem de sağlayan firma için oldukça önemlidir. Dolayısıyla personel memnuniyeti ve personellerin doğru işlere atanması sektörün gerekliliklerinden bir tanesidir. Çalışmada kullanılan model bu disiplin çerçevesinde kurulmuştur. Model; adaletli ve görev dağılım bilincini önemsemesinin yanında personellerin yetkinliklerini de aynı derecede dikkate alarak verimliliği optimize etmeyi amaçlamaktadır.

Böylece, literatüre özellikle de çok fazla çalışılmayan bir sektör için farklı yaklaşımlar da kullanarak katkıda bulunmayı hedeflemektedir.

\section{UYGULAMA (APPLICATION)}

Çalışmada, Kapadokya bölgesinde düzenlenen tanıtım festivalinde görev yapacak 84 adet personelin çizelgeleme problemi ele alınmıştır. Festivalde dört ana etkinlik bulunmaktadır ve bu etkinlikler günlere göre değişiklik gösterebilmektedir. Festivalde yapılacak her bir etkinlik beraberinde yeni personel ihtiyacı ve farklı yetkinlikler getirmektedir. Bu durum personel çizelgeme problemi oluşturmaktadır.
Organizasyonda personellerin atanacağ 16 farklı görev mevcuttur. Bu görevler: Süpervizör (SPV), Bilet Satış (BILETS), INFO, Bilet Kontrol (BILETK), Yönlendirme (YOK) ve Karşılama (KAR) şeklindedir. 15 gün boyunca sürecek olan organizasyon ülke turizmi için önem arz etmektedir. Organizasyonun kaliteli bir şekilde hiçbir aksama yaşamadan yürütülmesi temel amaçtır. $\mathrm{Bu}$ amaç doğrultusunda her bir görev için en uygun personellerin atanması amaçlanmaktadır.

Uygulama her bir görevdeki yetkinlik düzeyini ençoklamayı amaçlamaktadır. $\mathrm{Bu}$ doğrultuda personellerin her bir görev için yetkinlik puanları 0-10 skalasında belirlenmiştir. Ayrıca görevler de önem ağırlıklarına göre sıralanmış ve önem düzeyleri ile orantılı olarak yetkinlikleri ençoklanmıştır. Bu veriler ve sonuçlar, uygulama başlığının "veriler" ve "görev önceliklerinin belirlenmesi” başlıklarında detaylı olarak incelenmiştir. Uygulama akış şeması Şekil 3'te gösterilmiştir.

\subsection{Problem Tanımı (Problem Definition)}

Türkiye'de bulunan ve dünya çapında talep gören Kapadokya bölgesinde, tanitım festivali organizasyonu düzenlenecektir. 15 gün süren etkinlikle, bölgeye özellikle yabancı turist sayısının artması amaçlanmaktadır. Turizm sektöründeki rekabet ve karlılık düşünüldüğünde böyle bir organizasyonun beklentileri karşılaması oldukça önemlidir. Etkinlikte 84 personel 6 göreve atanacaktır. Organizasyonun herhangi bir aksaklık olmadan verimli bir şekilde yürütülmesi amaçlanmaktadır. $\mathrm{Bu}$ doğrultuda personellerin yetkin oldukları görevlere atanmaları, böylece beklenen hizmetin aksama olmadan sürdürülmesi amaçlanmaktadır. Organizasyon; hazırlık ve etkinlik olmak üzere 2 bölümden oluşmaktadır. Hazırlık bölümü organizasyon planlarının oluşturulduğu ve gerekli ekipmanların sağlandığı bölümdür. $\mathrm{Bu}$ bölümdeki hazırlıkların süresi 7 gün olarak belirlenmiştir. Etkinlik bölümü ise organizasyonun gerçekleştiği kısımdır. Hazırlıkların bitmesinin ardından festival bütün birimleri ile ziyaretçi kabul edebilmektedir. $\mathrm{Bu}$ bölüm ise 8 gün olarak planlanmıştır. 


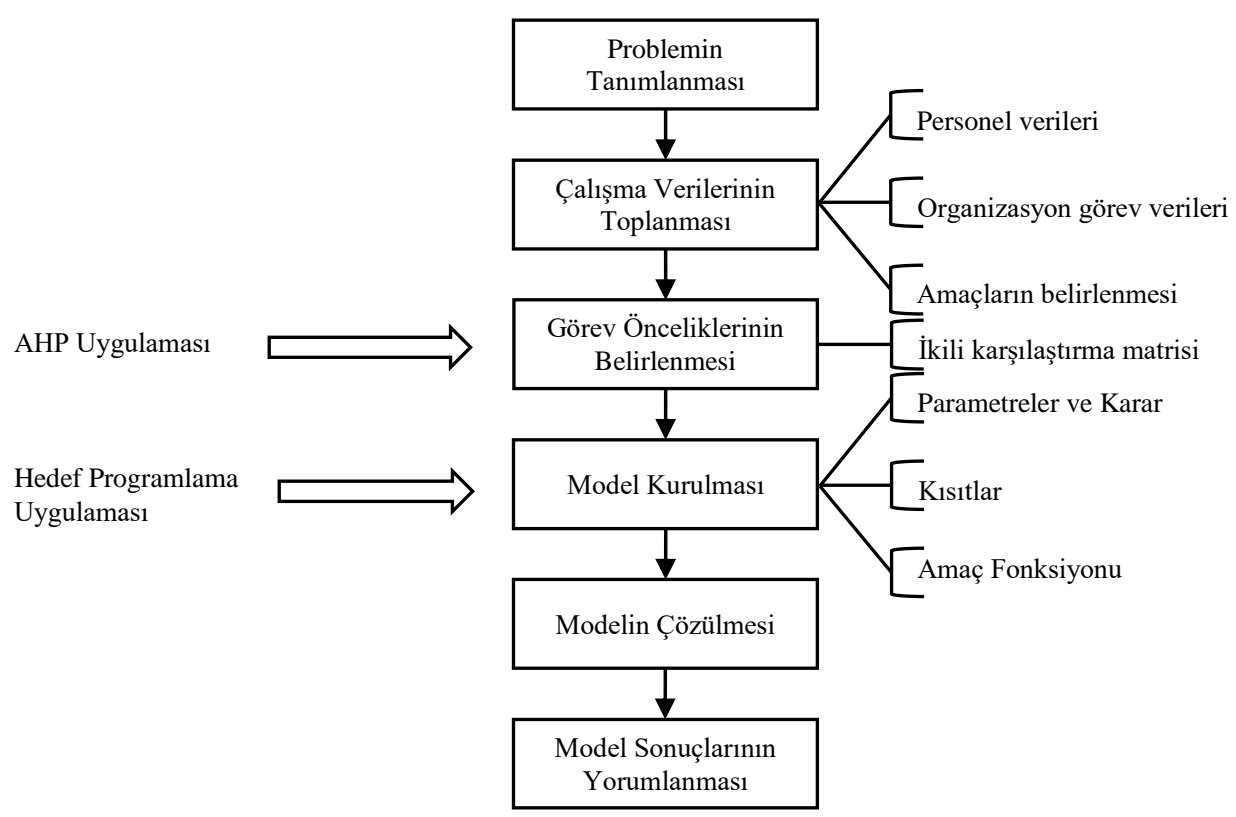

Şekil 3. Uygulama Akış Şeması (Application Flowchart)

$\mathrm{Bu}$ doğrultuda görevler farklı çalışma sürelerine sahiptir. SPV, BILETS ve INFO görevleri organizasyon boyunca (15 gün) aktif olacaklardır. BILETK görevi organizasyonun etkinlik bölümü itibariyle aktif olacaktır (son 8 gün).

YON görevi hazırlık bölümünün son günü ve etkinlik bölümü olmak üzere son 9 gün hazır bulunacaktır. KAR görevi ise organizasyon etkinlik bölümünün başı ve sonu olmak üzere; 7,8,14 ve 15 . gün olmak üzere toplam 4 gün aktif olacaktır.

Etkinlik için personel ihtiyacı bir organizasyon firması aracılığı ile karşılanmıştır. Personellerin her bir görev için yetkinlik puanları da söz konusu firmadan temin edilmiştir. Ek olarak organizasyon için tanımlanan 6 farklı görev de önceliklerine göre ağırlıklandırılmış ve ağırlıkları ile orantılı bir şekilde, günlük yetkinlik puanlarının ençoklanması, göz önünde bulundurulmuştur.

\subsection{Veriler (Data)}

Organizasyon için belirlenen görevler ile ilgili bilgiler Tablo 2'de gösterilmiştir.

Görevlerden sadece SPV görevi için çalışacak personeller belirlidir. Diğer bölümler için personel yetkinlikleri göz önüne alınmıştır. 1, 2, .., 7 numaralı personel uygunluklarından dolayı SPV görevinde çalışacaklardır. Personellerin $(\mathrm{P})$ yetkinlik verileri bir uzman ve 2 akademisyen görüşleri ile belirlenerek Tablo 3'te gösterilmiştir. Organizasyon firması yetkilisi uzman ve akademisyenlerin çalışması ile 1-9 puan skalasında görevlere göre yetkinlik puanları oluşturulmuştur.

\subsection{Görevlerin Önceliklendirilmesi (Prioritization of Tasks)}

Organizasyon çalışmasında, personellerin görevlendirileceği 6 adet iş AHP yöntemi kapsamında ikili karşılaştırma matrisine tabii tutularak karşılaştırılmıştır. Böylece görevlere önem dereceleri doğrultusunda öncelik verilerek daha kaliteli bir hizmet verilmesi amaçlanmaktadır.

SPV görevine atanacak personeller belirli olduğu için bu görev ikili karşılaştırılma matrisine dahil edilmemiştir. Görevlerin ikili karşılaştırma matrisi uzman görüşleri doğrultusunda oluşturulmuştur. $\mathrm{Bu}$ karşılaştırma ve görevlerin önem ağırlıkları 0-100 skalasında Tablo 4'te gösterilmiştir. 
Tablo 2. Görev Bilgileri (Task Information)

\begin{tabular}{|l|l|l|c|c|}
\hline Görev & Görev Tanımı & Personelde Aranan Nitelikler & Talep & Aktif günler \\
\hline SPV (S) & $\begin{array}{l}\text { Her birim için seçilen birim sorumlusu } \\
\text { personellerdir. }\end{array}$ & $\begin{array}{l}\text { Tecrübeli, problemleri hızlı çözebilecek } \\
\text { proaktif, müşteri ile direk iletişim } \\
\text { kurabilecek, }\end{array}$ & 7 & Hepsi (15) \\
\hline $\begin{array}{l}\text { BILETS } \\
\text { (B1) }\end{array}$ & $\begin{array}{l}\text { Organizasyon özelinde hazırlanan biletlerin } \\
\text { satışında görev alacak personellerdir. }\end{array}$ & $\begin{array}{l}\text { Bilgisayar bilgisi iyi, ikna kabiliyeti yüksek, } \\
\text { diksiyonu iyi seviyede, yabancı dil bilen }\end{array}$ & 10 & Hepsi (15) \\
\hline INFO (I) & $\begin{array}{l}\text { Bilgi almak için gelen kişileri doğru birime } \\
\text { yönlendirmek için bulunan personellerdir. }\end{array}$ & $\begin{array}{l}\text { Yönlendirme becerisi yüksek, bilet satışa } \\
\text { destek olabilecek, yabancı dil bilen }\end{array}$ & 4 & Hepsi (15) \\
\hline $\begin{array}{l}\text { BILETK } \\
\text { (B2) }\end{array}$ & $\begin{array}{l}\text { Biletli seyircilerin, giriş alanında biletlerini } \\
\text { kod okuyucu cihaz kullanarak içeri } \\
\text { girebilmelerini sağlayan personellerdir. }\end{array}$ & Fiziksel olarak uzun boylu olmak & 20 & Son 8 \\
\hline YON (Y) & $\begin{array}{l}\text { Katılımcılara alanda etkinlik noktalarına } \\
\text { yönlendirme yapan personellerdir. }\end{array}$ & $\begin{array}{l}\text { Diksiyonu düzgün, festival } \\
\text { Alanına hakim olan ve planları takip } \\
\text { edebilen }\end{array}$ & 35 & Son 9 \\
\hline KAR (K) & $\begin{array}{l}\text { Aktivitede yer alan konuşmacıların ve } \\
\text { sanatçların havaalanında karşıylayıp gerekli } \\
\text { yönlendirmeleri yapan personellerdir. }\end{array}$ & $\begin{array}{l}\text { Yabancı dil bilen, } \\
\text { Diksiyonu düzgün, } \\
\text { Bulunulan bölge hakkında bilgi sahibi } \\
\text { (Kapadokya) }\end{array}$ & 8 & $7,8,14$ ve 15. \\
\hline
\end{tabular}

Tablo 3. Personel Yetkinlik Puanları (Staff Competency Scores)

\begin{tabular}{|c|c|c|c|c|c|c|c|c|c|c|c|c|c|}
\hline $\mathbf{P}$ & \begin{tabular}{|l|}
$\mathbf{S}$ \\
\end{tabular} & 1 & I & 2 & $\mathbf{Y}$ & In & $P$ & & $\overline{B K}$ & $\mathbf{K}$ & $\mathbf{L}$ & & \\
\hline 1 & \begin{tabular}{|l|}
0 \\
\end{tabular} & & \begin{tabular}{|l|}
5 \\
\end{tabular} & - & 9 & & 43 & & 2 & 5 & 3 & & \\
\hline & 9 & & 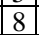 & 8 & & & 4 & & & 2 & 5 & ) & \\
\hline 3 & 8 & & & 7 & & & 5 & 2 & 2 & 3 & 4 & 3 & \\
\hline 4 & 9 & 8 & 8 & 7 & & 8 & 46 & 3 & 5 & 2 & 5 & 8 & \\
\hline 5 & 8 & 9 & 8 & 7 & 7 & 17 & \begin{tabular}{|l|}
47 \\
\end{tabular} & 6 & 3 & 4 & 3 & 9 & \\
\hline 6 & 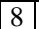 & 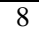 & 8 & 8 & 8 & 8 & 48 & 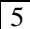 & 6 & 29 & 2 & 9 & \\
\hline 7 & 9 & & 8 & 8 & & , & 9 & \begin{tabular}{|l|}
1 \\
\end{tabular} & 5 & & 5 & 8 & \\
\hline 8 & 5 & & 3 & 5 & & & & 2 & 2 & & 6 & 9 & \\
\hline 9 & 4 & & 3 & 7 & & 5 & & 3 & 1 & 3 & 3 & 8 & \\
\hline 10 & 4 & & 4 & 7 & & 2 & 52 & \begin{tabular}{|l}
4 \\
\end{tabular} & 4 & 5 & 2 & 9 & \\
\hline 11 & 4 & c & 4 & 4 & & & 3 & 2 & 2 & 5 & 1 & 9 & \\
\hline 12 & 3 & 8 & 2 & 5 & & & 4 & 3 & 3 & 4 & 5 & 9 & \\
\hline 13 & 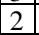 & 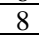 & 3 & 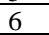 & & 2 & 55 & 5 & 2 & 1 & 5 & 9 & \\
\hline 14 & 3 & 8 & 3 & 2 & & 4 & 56 & 5 & 5 & 2 & 3 & 9 & \\
\hline 15 & \begin{tabular}{|l|}
3 \\
\end{tabular} & 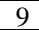 & 2 & 3 & 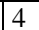 & 10 & \begin{tabular}{|l|}
57 \\
\end{tabular} & 5 & 3 & 3 & 2 & 8 & 4 \\
\hline 16 & 4 & 9 & - & 3 & & 4 & 58 & 4 & 5 & 2 & 5 & 8 & 5 \\
\hline 17 & 4 & 9 & 4 & 5 & & 4 & \begin{tabular}{|l}
59 \\
\end{tabular} & 4 & 5 & 5 & 3 & 9 & \\
\hline 18 & 5 & 3 & 9 & 5 & & 4 & & 2 & & 3 & 3 & 9 & \\
\hline 19 & 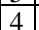 & 2 & 更 & 4 & & 5 & & \begin{tabular}{|l|}
2 \\
\end{tabular} & & 2 & ) & y & \\
\hline 20 & 5 & 3 & 9 & 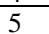 & & 3 & 62 & 1 & 5 & 5 & 5 & 9 & \\
\hline 21 & 5 & 3 & \begin{tabular}{|l|}
8 \\
\end{tabular} & 5 & & 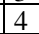 & 63 & 4 & 2 & 4 & 5 & 8 & 5 \\
\hline 22 & 4 & 3 & 4 & c & & 2 & $\begin{array}{l}64 \\
\end{array}$ & 5 & 3 & 2 & 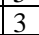 & 8 & \\
\hline 23 & 5 & 4 & 2 & 8 & & 5 & 65 & 2 & 2 & 3 & 2 & 9 & 5 \\
\hline 24 & 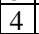 & 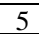 & 3 & c & & 5 & 66 & 3 & 5 & 5 & 3 & 9 & 0 \\
\hline 25 & 3 & 7 & 2 & 8 & 5 & 10 & \begin{tabular}{|l|}
67 \\
\end{tabular} & 1 & 2 & 2 & 5 & 9 & 4 \\
\hline 26 & 5 & 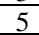 & 4 & 8 & 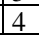 & 5 & $\begin{array}{l}68 \\
\end{array}$ & 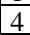 & 3 & 3 & 5 & 9 & 5 \\
\hline 27 & 4 & 2 & 5 & 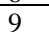 & & 4 & \begin{tabular}{|l}
69 \\
\end{tabular} & 2 & & 5 & 2 & 8 & \\
\hline 28 & 5 & 2 & 2 & 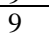 & 5 & t & \begin{tabular}{|l|}
70 \\
\end{tabular} & 1 & 5 & 2 & 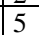 & 9 & 4 \\
\hline 29 & \begin{tabular}{|l|l|} 
\\
\end{tabular} & $\frac{1}{4}$ & \begin{tabular}{|l|} 
\\
\end{tabular} & 9 & & 5 & \begin{tabular}{|l|}
71 \\
\end{tabular} & \begin{tabular}{|l|} 
\\
3
\end{tabular} & & 4 & 5 & 8 & 1 \\
\hline 30 & 6 & 5 & 2 & 5 & & 5 & 2 & 4 & 3 & 2 & 3 & 8 & \\
\hline 31 & 2 & 3 & 5 & 8 & & 2 & \begin{tabular}{|l|}
73 \\
\end{tabular} & \begin{tabular}{|l|l} 
\\
\end{tabular} & 2 & 3 & 2 & 8 & \\
\hline 32 & 5 & 2 & $\vec{t}$ & 19 & & : & \begin{tabular}{|l}
74 \\
\end{tabular} & \begin{tabular}{|l|} 
\\
\end{tabular} & 5 & 2 & 5 & 9 & 5 \\
\hline 33 & 3 & 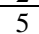 & 3 & 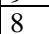 & & 3 & \begin{tabular}{|l|}
75 \\
\end{tabular} & 5 & 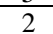 & \begin{tabular}{|l|}
5 \\
\end{tabular} & 6 & 8 & 3 \\
\hline 34 & 2 & 6 & 2 & 8 & 5 & 5 & $\begin{array}{l}76 \\
\end{array}$ & 3 & 3 & 2 & 3 & 9 & 2 \\
\hline 35 & 3 & 2 & 5 & 9 & 4 & 4 & \begin{tabular}{|l|}
77 \\
\end{tabular} & 2 & 1 & 3 & 2 & 3 & 9 \\
\hline 36 & 5 & 4 & 4 & 9 & 5 & 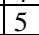 & 78 & 4 & 5 & 5 & 5 & 5 & 8 \\
\hline 37 & \begin{tabular}{|l|}
3 \\
\end{tabular} & 2 & 1 & 9 & 4 & 3 & \begin{tabular}{|l}
79 \\
\end{tabular} & 5 & 5 & 2 & 6 & 4 & 9 \\
\hline 38 & 2 & 2 & \begin{tabular}{|l|}
7 \\
\end{tabular} & 9 & 5 & 4 & \begin{tabular}{|l}
80 \\
\end{tabular} & 2 & 3 & 3 & 3 & 2 & 8 \\
\hline 39 & $\mid$ & 2 & 2 & $=$ & 4 & & 1 & \begin{tabular}{|l|}
3 \\
\end{tabular} & 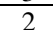 & 5 & 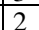 & 3 & O \\
\hline 40 & 5 & 5 & \begin{tabular}{|l|}
5 \\
\end{tabular} & \begin{tabular}{|l}
9 \\
\end{tabular} & 5 & & \begin{tabular}{|l|}
82 \\
\end{tabular} & 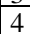 & 5 & \begin{tabular}{|l|}
4 \\
\end{tabular} & 5 & 5 & 8 \\
\hline 41 & 4 & 3 & 3 & 13 & 9 & & \begin{tabular}{|l|}
83 \\
\end{tabular} & 2 & 4 & 2 & 2 & 4 & 9 \\
\hline 42 & 3 & 5 & 6 & 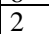 & 8 & 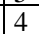 & $\begin{array}{l}84 \\
\end{array}$ & & 4 & 3 & 3 & 2 & \\
\hline
\end{tabular}

Tablo 4. Görevlerin İkili Karşılaştırma Matrisi (Binary Comparison Matrix of Tasks)

\begin{tabular}{|c|c|c|c|c|c|}
\hline GÖREVLER & INFO & KAR & YON & BILETS & BILETK \\
\hline INFO & 1 & 2,00 & 2 & 3 & 4 \\
\hline KAR & 0,50 & 1 & 2 & 2 & 4 \\
\hline YON & 0,50 & 0,50 & 1 & 3 & 3 \\
\hline BILETS & 0,33 & 0,50 & 0,33 & 1 & 3 \\
\hline BILETK & 0,25 & 0,25 & 0,33 & 0,33 & 1 \\
\hline $\begin{array}{c}\text { Önem } \\
\text { Ağırlığı }\end{array}$ & $\mathbf{3 6}$ & $\mathbf{2 5}$ & $\mathbf{2 0}$ & $\mathbf{1 2}$ & $\mathbf{7}$ \\
\hline
\end{tabular}

\subsection{Matematiksel Model (Mathematical Model)}

Bu bölümde 84 adet personelin 6 iş özelinde 15 günlük çizelgelemesine yer verilmiştir. Modelde her bir bölümün önem dereceleri ile orantılı yetkinlik puanlarının ençoklanması amaçlanmıştır.

\subsubsection{Parametreler (Parameters)}

\begin{tabular}{|c|c|c|}
\hline$n$ & : Personel sayıs1 & $n=84$ \\
\hline$m$ & : Gün say1sı & $m=15$ \\
\hline$t$ & : Görev sayısı & $t=6$ \\
\hline$i$ & : Personel indeksi & $i=1,2, \ldots \ldots, n$ \\
\hline$j$ & : Gün indeksi & $j=1,2, \ldots \ldots, m$. \\
\hline$k$ & : Görev indeksi & $k=1, \ldots t$ \\
\hline$M_{j k}$ & $\begin{array}{l}\text { : j. Günde k. görevin } \\
\text { personel ihtiyacı }\end{array}$ & $\forall \mathrm{j}, \mathrm{k}$ \\
\hline$F_{k}$ & $\begin{array}{l}\text { : k. görevin pasif olduğu } \\
\text { günler kümesidir (Tablo 2) }\end{array}$ & $\forall \mathrm{k}$ \\
\hline$Y_{i k}$ & : i. personelin k. Görevdeki & $\forall \mathrm{i}, \mathrm{k}$ \\
\hline
\end{tabular}
yetkinliği (Tablo 3)

$C_{k} \quad$ : k. görevin hedef yetkinlik $\quad \forall \in 2 \ldots 6$ değeri (Hedef kısıtı să̆ taraf değeri) 


\subsubsection{Karar değiş̧kenleri (Decision variables)}

Modelin karar değişkenleri aşağıda gösterilmiştir. i personel, $\mathrm{j}$ gün ve $\mathrm{k}$ görev ve indisleri olmak üzere modelin karar değişkeni aşağıda gösterilmiştir.

$\mathrm{X}_{\mathrm{ijk}}=\left\{\begin{array}{lr}1, & \text { i.personelin } j . g \mathrm{ün} k . g \text { öreve atanması durumu } \\ 0, & d d\end{array}\right\}$ $\forall \mathrm{i}, \mathrm{j}, \mathrm{k}$

Hedef karar değişkenleri aşağıda gösterilmiştir $\mathrm{Bu}$ karar değişkenlerinin sağ taraf değerleri $\left(C_{k}\right)$, görevli herkesin yetkinlik puanları 10'a eşit olması durumu ile kabul edilerek, maksimum olacak şekilde hesaplandığı için (toplam atama sayısı * 10) pozitif sapma beklenmemektedir. Dolayısıyla modelde sadece negatif sapmalar yer almıştır.

in $^{-}$: INFO görevinin negatif yetkinlik sapması $\mathrm{ka}^{-}$: KAR. görevinin negatif yetkinlik sapması $y o^{-}$: YON. görevinin negatif yetkinlik sapması $b s^{-}$: BILETS. görevinin negatif yetkinlik sapması $b k^{-}$: BILETK. görevinin negatif yetkinlik sapması

\subsubsection{Matematiksel modelin kisıtları (The constraints of the mathematical model)}

Modelin sert ve hedef kısıtları aşağıda açıklamaları ile gösterilmiştir. Dört adet kısıt ve beş adet ağırlıklandırılmış hedef kısıtı bulunmaktadır. SPV, BILETS, INFO, BILETK, YON ve KAR görevlerinin $\mathrm{k}$ indisleri sırası ile 1, 2, 3, 4, 5 ve 6'dır.

Kısıt 1: j. gün k. görevde ihtiyaç duyulan sayıda personelin atanmasını garanti eden kisit.

$\sum_{\mathrm{i}=1}^{84} \mathrm{x}_{\mathrm{ijk}}=M_{j k} \quad \forall \mathrm{j}, \mathrm{k}$

Kısıt 2: 1, 2, ., 7 numaralı personeller her gün SPV görevine atanmalıdır

$\mathrm{x}_{\mathrm{ij} 1}=1 \quad \mathrm{i}=1 \ldots 7, \forall \mathrm{j}$

Kısıt 3: Bir personel bir günde en fazla bir göreve atanabilir.

$\sum_{\mathrm{k}=1}^{6} \mathrm{x}_{\mathrm{ijk}} \leq 1$

$\forall \mathrm{i}, \mathrm{j}$

Kısıt 4: Eğer bir görev ilgili günde yapılmayacak ise o gün için o göreve personel atamasını engelleyen kısıt. $\sum_{\mathrm{i}=1}^{84} \mathrm{x}_{\mathrm{ijk}}=0$

$\forall \mathrm{k}, \mathrm{j} \in F_{k}$

Hedef Kısıtı: Modelde tüm görevlerin günlük yetkinlik puanının ençoklanması amaçlanmaktadır. Ayrıca bu durumu görevlerin önem dereceleri doğrultusunda dikkat edilmiştir. Böylece daha önemli bir görevin yetkinlik değeri daha öncelikli olarak ele alınacaktır. Bu kısıtlar eşitlik 8-12'de gösterilmiştir.

$\sum_{\mathrm{i}=1}^{84} \sum_{\mathrm{j}=1}^{15}\left(\mathrm{x}_{\mathrm{ij} 2} * Y_{i 2}\right)+b s^{-}=C_{2}$

$$
\begin{aligned}
& \sum_{\mathrm{i}=1}^{84} \sum_{\mathrm{j}=1}^{15}\left(\mathrm{x}_{\mathrm{ij} 3} * Y_{i 3}\right)+i n^{-}=C_{3} \\
& \sum_{\mathrm{i}=1}^{84} \sum_{\mathrm{j}=1}^{15}\left(\mathrm{x}_{\mathrm{ij} 4} * Y_{i 4}\right)+b k^{-}=C_{4} \\
& \sum_{\mathrm{i}=1}^{84} \sum_{\mathrm{j}=1}^{15}\left(\mathrm{x}_{\mathrm{ij} 5} * Y_{i 5}\right)+y o^{-}=C_{5} \\
& \sum_{\mathrm{i}=1}^{84} \sum_{\mathrm{j}=1}^{15}\left(\mathrm{x}_{\mathrm{ij} 6} * Y_{i 6}\right)+k a^{-}=C_{6}
\end{aligned}
$$

\subsubsection{Matematiksel modelin amaç fonksiyonu (Objective function of the mathematical model)}

Modelin ağırlıklandırılmış amaç fonksiyonu aşağıda gösterilmiştir. Sapmaların önem katsayıları Tablo 4'ten alınmıştır.

Minimize $\left(12 * b s^{-}\right)+\left(36 * \mathrm{in}^{-}\right)+\left(7 * b k^{-}\right)+$ $\left(20 * y o^{-}\right)+\left(25 * k a^{-}\right)$

\subsubsection{Matematiksel modelin çözümü (Solution of the mathematical model)}

7565 adet karar değişkeninin ve 1452 adet sert kısitın bulunduğu model IBM Ilog Cplex Optimization Studio programı ile Monster marka Abra a5 v12 model, Intel i5 7300 HQ işlemcili 8 gb ram bulunan bilgisayar kullanılarak çözülmüştür. Yapılan atama ile tüm kısıtlar sağlanırken tüm görevlerin önem derecelerine göre yetkinlikleri ençoklanmıştır. Personellerin her görev altındaki puan verileri ve AHP yönteminden elde edilen görevlerin önem puanları da modele dahil edilerek, bir gerçek hayat problemine uygun çözüm üretilmiştir. Bu sayede etkinlik sürecince, uzman kişilerce belirlenmiş önemli görevler için daha hassas bir çalışma yürütülerek hizmet kalitesi artırılmıştır. Hizmet kalitesinde personel memnuniyetinin önemi de dikkate alınarak personellerin yetkin oldukları işlere atanmasını sağlayan bir model kurulmuştur. Ek olarak bilimsel çalışmanın yürütülmediği bir çizelgeden elde edilen yetkinlik puanları da çözümde verilmiştir. Böylece yapılan çalışmanın önemi daha net bir şekilde anlaşılmaktadır. Model görev (GÖ) atama sonucu Tablo 5'te gösterilmiştir. 
Tablo 5. Model Sonucu (Solution of the Model)

\begin{tabular}{|c|c|c|c|c|c|c|c|c|c|c|c|}
\hline $\mathbf{P}$ & Gö & Gün & $\mathbf{P}$ & Gö & Gün & $\mathbf{P}$ & Gö & Gün & $\mathbf{P}$ & Gö & Gün \\
\hline 1 & S & $1-15$ & 22 & B2 & $8-15$ & 43 & $\mathrm{Y}$ & $7-15$ & 64 & $\begin{array}{l}\mathrm{Y} \\
\end{array}$ & $7-15$ \\
\hline 2 & S & $1-15$ & 23 & B2 & $8-15$ & 44 & $\mathrm{Y}$ & $7-15$ & 65 & $\begin{array}{l}\mathrm{Y} \\
\end{array}$ & $7-15$ \\
\hline 3 & S & $1-15$ & 24 & B2 & $8-15$ & 45 & $\mathrm{Y}$ & $7-15$ & 66 & $\begin{array}{l}\mathrm{Y} \\
\end{array}$ & $7-15$ \\
\hline 4 & S & 1-15 & 25 & B2 & $8-15$ & 46 & $\mathrm{Y}$ & 7-15 & 67 & $\begin{array}{l}\mathrm{Y} \\
\end{array}$ & $7-15$ \\
\hline 5 & S & $\mid 1-15$ & 26 & B2 & 8-15 & 47 & $\mathrm{Y}$ & $7-15$ & 68 & Y & $7-15$ \\
\hline 6 & $\mathrm{~S}$ & $1-15$ & $27 \mid$ & B2 & $8-15$ & \begin{tabular}{|l|}
48 \\
\end{tabular} & $Y$ & $7-15$ & \begin{tabular}{|l|}
69 \\
\end{tabular} & $\mathrm{Y}$ & $7-15$ \\
\hline 7 & S & $1-15$ & 28 & B2 & $8-15$ & \begin{tabular}{|l|}
49 \\
\end{tabular} & $\mathrm{Y}$ & $7-15$ & 70 & $\bar{Y}$ & $7-15$ \\
\hline 8 & B1 & $1-15$ & 29 & B2 & $8-15$ & 50 & $Y$ & $7-15$ & 71 & $\mathrm{Y}$ & $7-15$ \\
\hline 9 & B1 & 1-15 & 30 & B2 & $8-15$ & 51 & $Y$ & 7-15 & 72 & $\mathrm{Y}$ & $7-15$ \\
\hline 10 & B1 & $\mid 1-15$ & 31 & B2 & 8-15 & 52 & $\mathrm{Y}$ & 7-15 & 73 & $\mathrm{Y}$ & 7-15 \\
\hline 11 & B1 & $1-15$ & 32 & $\begin{array}{l}\text { B2 } \\
Y\end{array}$ & $8-15,7$ & 53 & $\mathrm{Y}$ & $7-15$ & 74 & $\mathrm{Y}$ & $7-15$ \\
\hline 12 & B1 & $1-15$ & 33 & B2 & $8-15$ & 54 & $Y$ & $7-15$ & 75 & B2 & $8-15$ \\
\hline 13 & B1 & $1-15$ & 34 & B2 & $8-15$ & 55 & $\mathrm{Y}$ & 7-15 & 76 & $\mathrm{Y}$ & $7-15$ \\
\hline 14 & B1 & $1-15$ & 35 & B2 & $8-15$ & 56 & $\mathrm{Y}$ & $7-15$ & 77 & K & $7,8,14,15$ \\
\hline 15 & B1 & $1-15$ & 36 & B2 & $8-15$ & 57 & $\mathrm{Y}$ & $7-15$ & 78 & K & $7,8,14,15$ \\
\hline 16 & B1 & $1-15$ & 37 & B2 & $8-15$ & 58 & $\mathrm{Y}$ & $7-15$ & 79 & $\mathrm{~K}$ & $7,8,14,15$ \\
\hline 17 & B1 & $1-15$ & 38 & B2 & $8-15$ & \begin{tabular}{|l|}
59 \\
\end{tabular} & $\mathrm{Y}$ & $7-15$ & 80 & K & $7,8,14,15$ \\
\hline 18 & & $1-15$ & 39 & B2 & $8-15$ & 60 & $\mathrm{Y}$ & $7-15$ & 81 & K & $7,8,14,15$ \\
\hline 19 & & $1-15$ & 40 & B2 & $8-15$ & 61 & $\mathrm{Y}$ & $7-15$ & 82 & $\mathrm{~K}$ & $7,8,14,15$ \\
\hline \begin{tabular}{|l|}
20 \\
\end{tabular} & & $1-15$ & 41 & $\mathrm{Y}$ & $7-15$ & \begin{tabular}{|l|}
62 \\
\end{tabular} & $\mathrm{Y}$ & $7-15$ & 83 & $\mathrm{~K}$ & $7,8,14,15$ \\
\hline 21 & & $1-15$ & 42 & $Y$ & $7-15$ & 63 & $\mathrm{Y}$ & $7-15$ & 84 & K & $7,8,14,15$ \\
\hline
\end{tabular}

Çalışma sonucunda elde edilen önerilen düzende çalışıldığında görevlerin ortalama yetkinlik puanları (GOYP) ve mevcut çalışma düzeninde GOYP karşılaştırılması Tablo 6'da gösterilmiştir. Tablodaki veriler, günlük olarak göreve atanan personellerin yetkinliklerinin toplamının personel sayısına bölümü ile elde edilmiştir. Daha sonra tüm günlerin ortalaması alınmıştır.

Tablo 6. Mevcut Durum ve Önerilen Durumda GOYP (Average Competency Scores of The Tasks in Current and Proposed Sitiation)

\begin{tabular}{|l|c|c|}
\hline Gö & $\begin{array}{l}\text { Önerilen Durum } \\
\text { GOYP }\end{array}$ & $\begin{array}{l}\text { Mevcut Durum } \\
\text { GOYP }\end{array}$ \\
\hline S & 8,571 & 8,571 \\
\hline B1 & 8,700 & 5,850 \\
\hline I & 8,500 & 5,236 \\
\hline B2 & 8,500 & 6,661 \\
\hline Y & 8,629 & 7,500 \\
\hline K & 8,500 & 5,500 \\
\hline
\end{tabular}

Kurulan bu modelde ağırlıklandırılmış amaç fonksiyonu ile sapmalar minimize edilmiştir. Bilimsel yöntemlerin kullanılmayıp manuel atama yapılması sonucunda elde edilen yetkinlik ortalama puanları ile önerilen durumda elde edilen puanların farkı açık bir şekilde görülmektedir.

Tablo 6'da gösterilen veriler göz önüne alındığında yapılan çalışmanın önemi anlaşılmaktadır. Personellerin yetkin oldukları işlere atanması sonucu görevlerdeki hizmet kalitesi de artacaktır. Bu şekilde daha kaliteli hizmet verilecek olup aynı zamanda aksamaların da önüne geçilebilecektir. Personellerin doğru işlere atanması sonucu personel memnuniyeti de artacaktır. Çalışma başında sadece SPV görevine atanacak personeller belliydi, dolayısıyla SPV görevinin yetkinlik ortalamasında bir değişim gözlenmemektedir. Ancak diğer görevlerin verileri incelendiğinde kurulan modelin başarılı bir sonuç verdiği anlaşılmaktadır.

\section{SONUÇ VE DEĞERLENDIRME (CONCLUSION AND EVALUATION)}

$\mathrm{Bu}$ çalışma, önemli bir turizm bölgesinin tanıtımı için düzenlenen bir organizasyonda görevli personellerin çalışma planlaması için gerçekleştirilmiştir. Turizm sektöründeki rekabet en çekişmeli rekabet ortamlarınındın bir tanesidir. Müşterilerin alternatifleri herhangi bir bölge ile sınırlı değildir. Dolayısıyla bu tarz organizasyonlardan beklenen hizmet kalitesi yüksektir ve bu beklentiyi karşılamak maddi açıdan oldukça karlı bir durumdur. Personellerin yetkin oldukları işlerde görevlendirilmesi hizmet kalitesi sağlama çalışmalarındaki ilk adımlardan birisidir. Çalışmada 15 gün süren bir etkinliğin personel çizelge çalışması yürütülmüştür. Özellikle personellerin yetkin oldukları görevlere atanması amaçlanmıştır. Etkinliğin sürdürülebilirliği için belirlenen görevler de ayrıca önceliklendirilerek, ağırlıklarına göre modele yansıtılmıştır. Ayrıca personel yetkinliklerinin dikkate alınmadığı bir çizelgenin görev yetkinlik sonuçları da çalışmada bir senaryo olarak gösterilmiştir. Model kısıtlara ve amaçlara verimli bir şekilde cevap vermiş ve 15 günlük çalışma çizelgesi oluşturulmuştur.

Literatürdeki çalışmalar incelendiğinde görülmektedir ki; personel çizelgeleme problemlerine birçok farklı yaklaşım sunulmuştur. Bu çalışmada ele alınan problem bir gerçek hayat problemidir. Çalışma, personel çizelgelerinin genel olarak manuel yapıldığı bir sektörde uygulanmıştır. Bu sektör diğer işkollarına nazaran en ufak hataların bile büyük zararlara yol açabileceği hassas bir çalışma disiplinine sahiptir. 
Personel memnuniyeti ve personellerin doğru işlere atanması son derece önemlidir. Çalışmada kullanılan modelde bu gibi durumlar dikkate alınmıştır. Model, görevleri önem dereceleri ile orantılı olacak şekilde dikkate alarak verimliliği optimize etmeyi amaçlamaktadır. Bu sayede kritik görevlere yapılan atamalar öncelikli olacaktır ve hizmet kalitesi görevin kritikliği ile orantılı şekilde sağlanacaktır. Görevlerin önem dereceleri de yine çalışmada yürütülen bilimsel yöntemle elde edilerek modele dahil edilmiştir. Böylece, literatüre özellikle de çok fazla çalışılmayan ancak çalışılmasının hizmet kalitesi için bir katkıdan çok gereklilik olduğu düşünülen bir sektör için katkıda bulunmayı hedeflemektedir.

İleride yürütülecek çalışmalara ilham olması açısından, görev önceliklendirme yöntemi tüm sektörler için kullanılabilir. Özellikle belirli işlerin baskın olarak önemli olduğu bir çalışma planında kullanılması verimlilik çıktısını önemli ölçüde artıracaktır. Bu tarz çalışmalarda ayrıca personellerin görev talepleri verisi de modele yansitilarak, personellerin daha dinamik bir şekilde çalışmalarına katkıda bulunulabilir. Özellikle işlerin değişkenlik gösterdiği organizasyon sektöründe, bu disiplinle kurulan model bir karar destek sistemine dönüştürülerek personel planlama çalışmaları kısa sürede ve devamlılığını koruyacak şekilde yürütülebilir.

\section{ÇIKAR ÇATIŞMASI BEYANI (CONFLICT OF INTEREST STATEMENT)}

Yazarlar tarafından herhangi bir çıkar çatışması bildirilmemiştir.

\section{KAYNAKLAR (REFERENCES)}

[1] Association of Turkish Travel Agencies, "Turizm gelirleri," tursab.or.tr, [Online]. Available: https://www.tursab.org.tr/istatistikler-icerik/turizmgeliri. [Accessed: Sept. 09, 2020].

[2] "2018'de 18 milyar dolarlık eğlence," Techinside.com, techinside.com, [Online]. Available: https://www.techinside.com/2018de-18-milyardolarlik-eglence. [Accessed: Sept. 09, 2020].

[3] H. A. Taha, Operations Research: An Introduction, 10th ed. Upper Saddle River, NJ: Pearson, 2016.

[4] Ö. Ünal, "Performans Değerlemede Analitik Hiyerarşi Prosesi (AHP) Uygulamaları," Sosyal
Bilimler Araştırmaları Dergisi, cilt 7, sayı 1, s. 37-55, Ocak 2012

[5] C.-C. Tsai and S. H. Li, "A two-stage modeling with genetic algorithms for the nurse scheduling problem," Expert Systems with Applications, vol. 36, no. 5, pp. 9506-9512, December 2009. doi: 10.1016/j.eswa.2008.11.049.

[6] N. Kaygısız, N. Girginer ve Z. Kaygısız, "İstatistiksel Yazılım Seçiminde Analitik Hiyerarşi Süreci ve 0-1 Hedef Programlama Yöntemlerinin Birlikte Kullanımı," Eskişehir Osmangazi Üniversitesi Sosyal Bilimler Dergisi, cilt 10, sayı 1, s. 211-233, Mart 2009

[7] M. Lezaun, G. Pérez, and E. Sáinz de la Maza, "Staff rostering for the station personnel of a railway company," Journal of the Operational Research Society, vol. 61, no. 7, pp. 1104-1111, July 2010. doi: 10.1057/jors.2009.48

[8] H.-T. Lin, Y.-T. Chen, T.-Y. Chou, and Y.-C. Liao, "Crew rostering with multiple goals: An empirical study," Computers \& Industrial Engineering, vol. 63, no. 2, pp. 483-493, April 2012. doi: 10.1016/j.cie.2012.04.013

[9] G. Bektur, ve S. Hasgül, "Kıdem Seviyelerine Göre İşgücü Çizelgeleme Problemi: Hizmet Sektöründe Bir Uygulama," Afyon Kocatepe Üniversitesi İktisadi ve İdari Bilimler Fakültesi Dergisi, cilt 15, say1 2, s. 385-402, Aralık 2013

[10] B. A. Kassa and A. E. Tizazu, "Personnel scheduling using an integer programming model- an application at Avanti Blue-Nile Hotels," Springerplus, vol. 2, no. 1, pp. 333, July 2013. doi: $10.1186 / 2193-1801-2-333$

[11] M. A. O. Louly, “A goal programming model for staff scheduling at a telecommunications center," Journal of Mathematical Modelling and Algorithms in Operations Research, vol. 12, no. 2, pp. 167-178, September 2013. doi: 10.1007/s10852-012-9200-x

[12] M. Labidi, M. Mrad, A. Gharbi, and M. A. Louly, "Scheduling IT staff at a bank: a mathematical programming approach," The Scientific World Journal, vol. 2014, p. 768374, March 2014. doi: $10.1155 / 2014 / 768374$

[13] Y. Öztürkoğlu ve F. Çalışkan, "Hemşire Çizelgelemesinde Esnek Vardiya Planlaması ve 
Hastane Uygulamas1," Dokuz Eylül Üniversitesi Sosyal Bilimler Enstitüsü Dergisi, cilt 16, sayı 1, s. 115-133, Nisan 2014. doi: 10.16953/deusbed.07850

[14] D. Todovic, D. Makajic-Nikolic, M. KosticStankovic, and M. Martic, "Police officer scheduling using goal programming," Policing: An International Journal, vol. 38, no. 2, pp. 295-313, May 2015. doi: 10.1108/PIJPSM-11-2014-0124

[15] T. Eren ve F. Ünal, "Hedef Programlama ile Nöbet Çizelgeleme Probleminin Çözümü," Akademik Platform Mühendislik ve Fen Bilimleri Dergisi, cilt 4, say1 1, s. 28-37, Ocak 2016. doi:10.21541/apjes.59022

[16] C. Ciritcioğlu, S. Akgün, E. Varlı ve T. Eren, "Kırıkkale Üniversitesi Güvenlik Görevlileri İçin Vardiya Çizelgeleme Problemine Bir Çözüm Önerisi," Uluslararast Mühendislik Araştırma ve Geliştirme Dergisi, cilt 9, sayı 2, s. 1-23, Haziran 2017. doi: 10.29137/umagd.351463

[17] N. Bedir, T. Eren ve E. N. Dizdar, "Ergonomik Personel Çizelgeleme ve Perakende Sektöründe Bir Uygulama," Mühendislik Bilimleri ve Tasarm Dergisi, cilt 5, say1 3, s. 657-674, Aralık 2017. doi: 10.21923/jesd.331259

[18] T. Eren, E. Özder ve E. Varlı, "Hedef Programlama Yaklaşımı ile Temizlik Personeli Çizelgeleme Problemi İçin Bir Model Önerisi," Karadeniz Fen Bilimleri Dergisi, cilt 7, sayı 2, s. 114127, Aralık 2017. doi:10.31466/kfbd.342344

[19] Ş. Gür, M. Hamurcu ve T. Eren, "Ankara'da Monoray projelerinin analitik hiyerarşi prosesi ve $0-1$ hedef programlama yöntemleri ile seçimi," Pamukkale Üniversitesi Mühendislik Bilimleri Dergisi, cilt 23, say1 4, s. 437-443, Ağustos 2017.

[20] E. Varlı, H. M. Alağaş, T. Eren and E. Özder, "Goal Programming Solution of the Examiner Assignment Problem," Bilge International Journal of Science and Technology Research, vol. 1, no. 2, pp. 105-118, November 2017.

[21] P. De Bruecker, J. Beliën, J. Van den Bergh, and E. Demeulemeester, "A three-stage mixed integer programming approach for optimizing the skill mix and training schedules for aircraft maintenance," European Journal of Operational Research, vol. 267, no. 2, pp. 439-452, November 2018. doi: 10.1016/j.ejor.2017.11.047
[22] H. Vermuyten, J. Namorado Rosa, I. Marques, J. Beliën, and A. Barbosa-Póvoa, "Integrated staff scheduling at a medical emergency service: An optimisation approach," Expert Systems with Applications, vol. 112, pp. 62-76, June 2018. doi: 10.1016/j.eswa.2018.06.017

[23] S. Koçtepe, N. Bedir, T. Eren ve Ş. Gür, "Organizasyon Görevlileri İçin Personel Çizelgeleme Probleminin 0-1 Tam Sayılı Programlama ile Çözümü," Ekonomi, İşletme ve Yönetim Dergisi, cilt 2, sayı 1, s. 25-46, Haziran 2018.

[24] B. Uslu, N. Bedir, Ş. Gür ve T. Eren, "0-1 Hedef Programlama Yöntemi Kullanılarak Hemşire Çizelgeleme Probleminin Çözümü," Sağlık Akademisi Kastamonu, cilt 3, say1 3, s. 148-170, Aralık 2018. doi: 10.25279/sak.383756

[25] T. Eren, A. Yelek, B. Demirel ve H. Alağaş, "Kısmi Zamanlı Çalışan Personellerin Çizelgelenmesi: Kırıkkale Üniversitesi Merkez Kütüphanesi Örneği," Kırıkkale Üniversitesi Sosyal Bilimler Dergisi, cilt 8, sayı 2, s. 313-330, Temmuz 2018.

[26] B. Demirel, A. Yelek, H. Alağaş ve T. Eren, "ANKARAY Güvenlik Personelinin Vardiya Çizelgeleme Probleminin Hedef Programlama Yöntemi ile Çözümü," Demiryolu Mühendisliği, say1 8, s. 1-17, Haziran 2018.

[27] S. Koçtepe, H. Alakaş, Ş. Gür ve T. Eren, "Basketbol Karşılaşmasında Görevli Organizasyon Personellerinin 0-1 Tam Sayılı Programlama Yöntemi ile Çizelgelenmesi," Başkent Üniversitesi Ticari Bilimler Fakültesi Dergisi, cilt 3, sayı 2, s. 44-53, Eylül 2019.

[28] S. Kaçmaz, H. Alakaş and T. Eren, "Ergonomic Staff Schedulıng Problem with Goal Programming in Glass Industry," Journal of Turkish Operations Management, vol. 4, no. 1, pp. 369-377, June 2020.

[29] E. Özcan, T. Danışan ve T. Eren, "Hidroelektrik santrallarda bakım çizelgeleme için hibrid bir model önerisi," Gazi Üniversitesi Mühendislik Mimarlık Fakültesi Dergisi, cilt 35, say1 4, s. 1815-1828, Temmuz 2020. doi:10.17341/gazimmfd.602774

\section{Ahmet CÜREBAL}

1992 yılında Soma/Manisa'da doğdu. İlk, orta ve lise öğrenimini Ankara'da tamamladı. 2018 yılında 
Kırıkkale Üniversitesi Endüstri Mühendisliğinden mezun oldu. Kırıkkale Üniversitesinin aynı bölümünde yüksek lisans eğitimine 2019 yllından beri devam etmektedir.

\section{Serkan KOÇTEPE}

1991 y1lında Sivas'ta doğmuştur. İlk, orta ve lise eğitimini Ankara'da tamamladı. Kırıkkale üniversitesi Endüstri mühendisliğinden 2019 yılında mezun olmuştur. Endüstri mühendisliği alanında yüksek lisans programına 2019 yılında Kirıkkale üniversitesinde başladı.

\section{Tamer EREN}

1974 Balıkesir doğumludur. İlk orta ve lise eğitimini Balıkesir'de tamamlamıştır. Selçuk Üniversitesi, Mühendislik-Mimarlık Fakültesi, Endüstri Mühendisliği bölümünden 1996 yllında mezun olmuştur. Kırıkkale Üniversitesi, Mühendislik Fakültesi Endüstri Mühendisliği Bölümünde 1997 yılında araştırma görevlisi olarak göreve başlamıştır. Gazi Üniversitesi Endüstri Mühendisliği bölümünde 1999 yllında araştırma görevlisi olarak görevlendirilmiştir. Aynı Üniversitede 2000 yılında yüksek lisansını, 2004 yılında da doktorasını tamamlayıp, Kırıkkale Üniversitesi Endüstri Mühendisliği bölümüne dönmüştür. 2004-2009 yılları arasında Araştırma Görevlisi Dr. olarak çalışmıştır. Aynı Üniversite'de 2009 yılından itibaren Yardımc1 Doçent, 2013 y1lından itibaren Doçent, 2019 yılından itibaren ise Profesör olarak çalışmaktadır. Yöneylem Araştırması anabilim dalında çalışan Eren'in çalışma alanı çizelgeleme ve çok ölçütlü karar vermedir. 